\title{
Evaluation of the Mineral Concentration in Beef from Polish Native Cattle
}

\author{
Piotr Domaradzki $^{1}$ - Mariusz Florek ${ }^{1}$ - Agnieszka Staszowska ${ }^{1}$. \\ Zygmunt Litwińczuk ${ }^{2}$
}

Received: 5 July 2015 / Accepted: 18 October 2015 /Published online: 26 October 2015

(C) The Author(s) 2015. This article is published with open access at Springerlink.com

\begin{abstract}
The aim of the study was to determine the content of macrominerals and microminerals in the longissimus lumborum (LL) and semitendinosus (ST) muscles of young bulls of five breeds - Polish Red (PR), White-Backed (WB), Polish Black-and-White (PBW), Simmental (SIM) and Polish Holstein-Friesian (PHF). The meat of the Polish HolsteinFriesian bulls was found to contain significantly less $\mathrm{K}, \mathrm{Mg}$ and $\mathrm{Ca}$ and more $\mathrm{Mn}$ than other breeds. The meat of the White-Backed bulls contained significantly $(P<0.01)$ more $\mathrm{Ca}$ and less $\mathrm{Na}$ than the meat of the Polish Red, Simmental and Polish Holstein-Friesian breeds. Moreover, the meat of White-Backed bulls showed a significantly $(P<0.01)$ higher level of $\mathrm{Mn}$ and $\mathrm{Cu}$ in comparison with other native breeds (Polish Red and Polish Black-and-White) and the Simmental breed. Similar content of macronutrients was found in the LL and ST muscles. However, in the case of micronutrients, the LL muscle contained significantly more $\mathrm{Zn}, \mathrm{Fe}$ and $\mathrm{Cu}$ as well as $\operatorname{Mn}(P>0.05)$.
\end{abstract}

Keywords Beef · Minerals · Polish native cattle breeds ·

Polish Red · White-Backed · Polish Black-and-White ·

Simmental · Polish Holstein-Friesian

Piotr Domaradzki

piotr.domaradzki@up.lublin.pl

1 Department of Commodity Science and Processing of Animal Raw Materials, University of Life Sciences in Lublin, Akademicka 13, 20-950 Lublin, Poland

2 Department of Breeding and Conservation of Genetic Resources of Cattle, University of Life Sciences in Lublin, Akademicka 13, 20-950 Lublin, Poland

\section{Introduction}

Red meat (mainly beef) is an important source of minerals in the human diet, supplying essential elements with high availability, particularly Fe and $\mathrm{Zn}$ [1-4]. The bioavailability of trace elements from beef ranges from 30 to $45 \%$ for $\mathrm{Cu}$, from 40 to $68 \%$ for $\mathrm{Zn}$, from 55 to $95 \%$ for $\mathrm{Mn}$ and from 60 to $70 \%$ for $\mathrm{Fe}$ [5]. Iron in meat occurs mainly in its easily available haem form, which is bound with myoglobin and haemoglobin. Its absorption from meat (from 20 to $30 \%$ ) is nearly twice as high as absorption from plants, although in the case of plants consumed together with meat, iron absorption can even double. Similarly, absorption of zinc from a diet rich in animal protein is greater than in the case of foods of plant origin [6].

In Poland, as in many countries of Central Europe, the most beef is obtained from cattle breeds used for dairy purposes. This, however, is a varied population, ranging from typically dairy cows (Holstein-Friesian, Jersey) to small populations of native breeds, i.e. those occurring in only one country. All four of the Polish native cattle breeds (Polish Red, White-Backed, Polish Black-and White and Polish Red-and-White) are kept on low-input farms where livestock is raised extensively, i.e. pastured in the summer and fed on-farm fodder (silage and hay) in the winter [7]. This type of production system is a key factor determining the high nutritional value of the meat obtained [8]. It is worth emphasising that the literature contains no reports on the mineral concentrations in the meat of Polish native cattle breeds.

The aim of the study was to compare the content of macroand microminerals in meat of young bulls of five breeds including three natives-Polish Red, White-Backed, Polish Black-and-White, as well as Simmental and Polish HolsteinFriesian. Additionally, the effect of muscle on mineral concentration was estimated. 


\section{Material and Methods}

\section{Samples}

The research material consisted of samples of the longissimus lumborum (LL, $n=40$ ) and semitendinosus (ST, $n=40$ ) muscles collected from the carcasses of young bulls of five breeds (eight from each breed). The calves included in the experiment were purchased in southeastern Poland from local breeders. During the initial period, calves were fed with milk and milk substitutes and subsequently grass forage, hay and concentrate (up to 6 months of age). The mean body mass of the calves at 6 months of the Polish Red (PR), White-Backed (WB) Polish Black-and-White (PBW) Polish Holstein-Friesian (PHF) and Simmental (SIM) breed were 178.8, 190.6, 199.8, 179.1 and $167.9 \mathrm{~kg}$, respectively.

After this period, the semi-intensive fattening was initiated and continued for 12 months, including both a winter and a summer feeding season. The animals were housed in a tie-stall system. The basic feed during the winter consisted of hay (47\% DM) and maize silage $(42 \% \mathrm{DM})$ and in the summer mainly grass forage (49 \%) supplemented with maize silage $(20 \%)$ and hay $(19 \%)$. The feed rations were supplemented with small amounts of grain meal (about 11-12\%). The bulls were slaughtered at an average age of 18 months. The mean body mass of bulls at slaughter and range of carcass conformation and fatness classes (according to the EUROP scale) was $506 \mathrm{~kg}, \mathrm{R}^{-}-\mathrm{O}^{0}, 2^{-}-2^{+}$for PR; $563 \mathrm{~kg}, \mathrm{R}^{-}-\mathrm{O}^{0}, 2^{-}-3^{0}$ for $\mathrm{WB} ; 593 \mathrm{~kg}, \mathrm{R}^{-}-\mathrm{O}^{0}, 2^{-}-3^{0}$ for PBW; $532 \mathrm{~kg}, \mathrm{R}^{-}-\mathrm{O}^{0}, 2^{-}-3^{0}$ for PHF; and $532 \mathrm{~kg}$, $\mathrm{U}^{0}-\mathrm{O}^{0}, 2^{-}-3^{-}$for SIM, respectively.

Muscle samples were collected during dissection of the right half of the carcasses (following 24-h refrigeration at $2{ }^{\circ} \mathrm{C}$, relative humidity $85 \%$ ), vacuum-packed in PA/PE vacuum bags and stored at $2-4{ }^{\circ} \mathrm{C}$ until analysis, $48 \mathrm{~h}$ after slaughter.

\section{Sample Preparation and Analysis}

The muscle samples $(1 \mathrm{~g})$ were wet-digested with $9 \mathrm{ml}$ concentrated nitric acid using a MarsXpress microwave oven (CEM Corporation, Matthews, NC, USA). Digested samples were transferred to polypropylene tubes and diluted to $25 \mathrm{ml}$ with ultrapure water. A blank digest $\left(9 \mathrm{ml} \mathrm{HNO}_{3}\right)$ was carried out in the same way. The concentration of macrominerals (potassium, sodium, calcium and magnesium) and microminerals (zinc, iron, manganese and copper) was determined by means of flame atomic absorption spectrometry (FAAS; air-acetylene flame) using a Varian Spectra 240FS spectrometer.

In order to determine sodium and potassium levels, a solution of caesium chloride was added as a deionised buffer to all of the samples and standards. A lanthanum chloride solution was used as a correction buffer to determine calcium and potassium. During the analysis, deuterium background correction was used and limits of quantification (LOQ) and detection (LOD) were taken into account. The method accuracy was evaluated using minerals determined in the Standard Reference Material 1577c Bovine Liver. The limits of detection, certified and measured value as well as recovery are presented in Table 1. The analyses were performed in triplicate. The content of macro- and microminerals in the samples was expressed in milligram per kilogram wet mass.

\section{Statistical Analysis}

The statistical analyses were performed using SAS Enterprise Guide 6.1 software (SAS Institute Inc.). To test the normality and the homogeneity of variance of data, KolmogorovSmirnov's test and Levene's $F$ test, respectively, were used. One-way analysis of variance (ANOVA), followed by Tukey's (HSD) test, was used to compare means of mineral concentration in the muscles (LL vs. ST) or in the meat of different cattle breeds (PR, WB, PBW, SIM and PHF). Twoway ANOVA (with GLM procedure) was also employed to
Table 1 The detection limits (LOD), minerals concentrations and recoveries (mean \pm standard deviation)

\begin{tabular}{|c|c|c|c|c|}
\hline & \multirow[t]{2}{*}{$\mathrm{LOD}(\mathrm{mg} / \mathrm{kg})$} & \multicolumn{2}{|c|}{$\begin{array}{l}\text { Standard reference material } \\
1577 \mathrm{c} \text { Bovine Liver }\end{array}$} & \multirow[t]{2}{*}{ Recovery $(\%)$} \\
\hline & & Certified value $(\mathrm{mg} / \mathrm{kg})$ & Measured value (mg/kg) & \\
\hline $\mathrm{K}$ & 0.04 & $10,230 \pm 640$ & $9868.63 \pm 480.71$ & 96.5 \\
\hline $\mathrm{Na}$ & 0.01 & $2033 \pm 64$ & $2086.09 \pm 69.23$ & 102.6 \\
\hline $\mathrm{Ca}$ & 0.22 & $131 \pm 10$ & $140.35 \pm 6.63$ & 107.1 \\
\hline $\mathrm{Mg}$ & 0.47 & $620.42 \pm 42$ & $627.05 \pm 42.06$ & 101.1 \\
\hline $\mathrm{Zn}$ & 0.01 & $181.10 \pm 1.00$ & $176.11 \pm 4.54$ & 97.2 \\
\hline $\mathrm{Fe}$ & 0.09 & $197.94 \pm 0.65$ & $196.51 \pm 2.09$ & 99.8 \\
\hline $\mathrm{Mn}$ & 0.01 & $10.46 \pm 0.47$ & $10.49 \pm 0.71$ & 100.3 \\
\hline $\mathrm{Cu}$ & 0.01 & $275.20 \pm 4.60$ & $287.19 \pm 7.02$ & 104.4 \\
\hline
\end{tabular}


Table 2 Statistical $P$ values from the two-way ANOVA for breed and muscle and their interactions

\begin{tabular}{llll}
\hline Effect tested & Breed & Muscle & Interaction \\
\hline $\mathrm{K}$ & $* *$ & $\mathrm{NS}$ & $* *$ \\
$\mathrm{Na}$ & $* *$ & $\mathrm{NS}$ & $\mathrm{NS}$ \\
$\mathrm{Mg}$ & $* *$ & $\mathrm{NS}$ & $\mathrm{NS}$ \\
$\mathrm{Ca}$ & $* *$ & $\mathrm{NS}$ & $\mathrm{NS}$ \\
$\mathrm{Zn}$ & $* *$ & $*$ & $\mathrm{NS}$ \\
$\mathrm{Fe}$ & $* *$ & $\mathrm{NS}$ \\
$\mathrm{Mn}$ & $\mathrm{NS}$ & $\mathrm{NS}$ & $* *$ \\
$\mathrm{Cu}$ & $* *$ & $* *$ & $\mathrm{NS}$ \\
\hline
\end{tabular}

NS not significant

$* P<0.05 ; * * P<0.01$

determine if interactions exist. Differences between means at confidence levels of 95 and $99 \%(P<0.05$ and $P<0.01$, respectively) were considered statistically significant. In Table 2, the mean value, standard error and range were presented.

\section{Results and Discussion}

The study showed that breed had a significant effect on the content of seven out of eight evaluated minerals and the type of muscle on the content of three elements. The significant interaction of both factors (breed $\mathrm{x}$ muscle) was found only for $\mathrm{K}$ and Mn (Table 2).

According to Cabrera et al. [1] and Ramos et al. [5], the most important factors influencing the proportions of minerals in cattle meat include breed, age, diet and production system, as well as the meat processing.

Our study showed that the meat of the PHF bulls contained significantly less $\mathrm{K}, \mathrm{Mg}$ and $\mathrm{Ca}$ than beef of other breeds analysed (Table 3). The reverse tendency was observed in the case of the microminerals. The meat of the PHF bulls showed the highest content of most $\mathrm{Mn}(P<0.01)$ and $\mathrm{Fe}$ $(P>0.05)$, as well as significantly more $\mathrm{Zn}$ than in the PR and SIM breeds $(P<0.01)$. The meat of the WB bulls contained significantly $(P<0.01)$ more $\mathrm{Ca}$ and less $\mathrm{Na}$ than the meat of the PR, SIM and PHF breeds. Moreover, the meat of WB bulls showed a significantly $(P<0.01)$ higher level of $\mathrm{Mn}$ and $\mathrm{Cu}$ in comparison with other native breeds (PR and PBW) and the SIM breed.

The results of this study are similar to those obtained earlier by Florek et al. [9] for most of the minerals ( $\mathrm{K}, \mathrm{Mg}, \mathrm{Ca}, \mathrm{Zn}$ and $\mathrm{Fe}$ ) determined in the muscles of young PHF bulls raised in eastern Poland.

The latest literature data also confirm that breed is a significant factor determining the content of minerals in the muscles of cattle raised under the same conditions [1, 5, 10]. Holló et al. [11] found significantly lower content of $\mathrm{Ca}$ and $\mathrm{Na}$ in the LL muscle of young bulls of the breed Hungarian Grey than in Holstein-Friesians. In the case of $\mathrm{Mg}, \mathrm{K}, \mathrm{P}, \mathrm{Cu}, \mathrm{Zn}$ and

Table 3 Content of macro- and microminerals (in milligram per kilogram of fresh tissue) in the meat of young bulls depending on the breed and muscle (mean \pm standard error and range in parentheses)

\begin{tabular}{|c|c|c|c|c|c|c|c|}
\hline & \multicolumn{5}{|l|}{ Breed } & \multicolumn{2}{|l|}{ Muscle } \\
\hline & $\mathrm{PR}(n=16)$ & $\mathrm{WB}(n=16)$ & $\mathrm{PBW}(n=16)$ & $\operatorname{SIM}(n=16)$ & $\operatorname{PHF}(n=16)$ & $\mathrm{LL}(n=40)$ & $\mathrm{ST}(n=40)$ \\
\hline $\mathrm{K}$ & $\begin{array}{l}3838.03^{C} \pm 68.75 \\
(3410.80-4346.09)\end{array}$ & $\begin{array}{l}3764.26^{\mathrm{BC}} \pm 95.72 \\
(3182.41-4355.53)\end{array}$ & $\begin{array}{l}3598.13^{\mathrm{BC}} \pm 77.75 \\
(3054.49-4169.20)\end{array}$ & $\begin{array}{l}3457.50^{\mathrm{B}} \pm 58.85 \\
(2984.27-3903.80)\end{array}$ & $\begin{array}{l}3204.80^{\mathrm{A}} \pm 63.89 \\
(2519.70-3678.26)\end{array}$ & $\begin{array}{l}3566.06 \pm 57.14 \\
(2738.94-4355.53)\end{array}$ & $\begin{array}{l}3579.03 \pm 66.84 \\
(2519.70-4346.09)\end{array}$ \\
\hline $\mathrm{Na}$ & $\begin{array}{l}483.55^{\mathrm{B}} \pm 37.09 \\
(278.61-795.05)\end{array}$ & $\begin{array}{l}352.64^{\mathrm{A}} \pm 11.22 \\
(299.52-450.43)\end{array}$ & $\begin{array}{l}414.94^{\mathrm{AB}} \pm 23.60 \\
(303.73-632.42)\end{array}$ & $\begin{array}{l}509.92^{\mathrm{B}} \pm 15.11 \\
(444.96-644.51)\end{array}$ & $\begin{array}{l}471.18^{\mathrm{B}} \pm 25.70 \\
(305.20-683.04)\end{array}$ & $\begin{array}{l}462.30 \pm 18.30 \\
(299.52-795.05)\end{array}$ & $\begin{array}{l}430.59 \pm 16.36 \\
(278.61-644.51)\end{array}$ \\
\hline $\mathrm{Mg}$ & $\begin{array}{l}319.49^{\mathrm{B}} \pm 4.83 \\
(280.49-361.91)\end{array}$ & $\begin{array}{l}299.10^{\mathrm{B}} \pm 8.59 \\
(245.14-345.65)\end{array}$ & $\begin{array}{l}320.90^{\mathrm{B}} \pm 7.35 \\
(297.46-381.65)\end{array}$ & $\begin{array}{l}312.54^{\mathrm{B}} \pm 7.60 \\
(259.65-364.56)\end{array}$ & $\begin{array}{l}236.88^{\mathrm{A}} \pm 7.37 \\
(175.05-276.80)\end{array}$ & $\begin{array}{l}297.49 \pm 5.96 \\
(203.54-381.65)\end{array}$ & $\begin{array}{l}298.07 \pm 7.45 \\
(175.05-376.93)\end{array}$ \\
\hline $\mathrm{Ca}$ & $\begin{array}{l}35.42^{\mathrm{B}} \pm 1.69 \\
(25.69-49.10)\end{array}$ & $\begin{array}{l}43.94^{\mathrm{C}} \pm 2.36 \\
(26.27-56.10)\end{array}$ & $\begin{array}{l}41.65^{\mathrm{BC}} \pm 2.84 \\
(30.29-66.64)\end{array}$ & $\begin{array}{l}33.58^{\mathrm{B}} \pm 0.97 \\
(26.55-39.30)\end{array}$ & $\begin{array}{l}20.41^{\mathrm{A}} \pm 2.10 \\
(11.90-40.35)\end{array}$ & $\begin{array}{l}37.12 \pm 1.99 \\
(11.90-66.64)\end{array}$ & $\begin{array}{l}32.88 \pm 1.63 \\
(12.43-55.76)\end{array}$ \\
\hline $\mathrm{Zn}$ & $\begin{array}{l}30.58^{\mathrm{AB}} \pm 20.56 \\
(20.56-43.26)\end{array}$ & $\begin{array}{l}36.81^{\mathrm{BC}} \pm 27.88 \\
(27.88-56.16)\end{array}$ & $\begin{array}{l}38.01^{\mathrm{C}} \pm 25.16 \\
(25.16-47.57)\end{array}$ & $\begin{array}{l}25.69^{\mathrm{A}} \pm 13.45 \\
(13.45-34.54)\end{array}$ & $\begin{array}{l}41.17^{\mathrm{C}} \pm 31.34 \\
(31.34-56.07)\end{array}$ & $\begin{array}{l}36.69^{\mathrm{y}} \pm 1.25 \\
(20.72-56.16)\end{array}$ & $\begin{array}{l}32.81^{x} \pm 1.35 \\
(13.45-47.61)\end{array}$ \\
\hline $\mathrm{Fe}$ & $\begin{array}{l}21.36 \pm 1.57 \\
(12.21-30.58)\end{array}$ & $\begin{array}{l}19.56 \pm 0.85 \\
(14.12-27.44)\end{array}$ & $\begin{array}{l}18.81 \pm 1.24 \\
(11.62-27.83)\end{array}$ & $\begin{array}{l}17.66 \pm 2.02 \\
(6.58-32.19)\end{array}$ & $\begin{array}{l}21.77 \pm 1.26 \\
(11.05-27.93)\end{array}$ & $\begin{array}{l}21.78^{\mathrm{Y}} \pm 0.88 \\
(12.00-32.19)\end{array}$ & $\begin{array}{l}17.88^{\mathrm{X}} \pm 0.87 \\
(6.58-27.93)\end{array}$ \\
\hline $\mathrm{Mn}$ & $\begin{array}{l}0.13^{\mathrm{A}} \pm 0.01 \\
(0.10-0.19)\end{array}$ & $\begin{array}{l}0.36^{\mathrm{B}} \pm 0.11 \\
(0.11-1.45)\end{array}$ & $\begin{array}{l}0.12^{\mathrm{A}} \pm 0.01 \\
(0.08-0.17)\end{array}$ & $\begin{array}{l}0.15^{\mathrm{A}} \pm 0.01 \\
(0.09-0.19)\end{array}$ & $\begin{array}{l}0.59^{\mathrm{C}} \pm 0.06 \\
(0.21-0.86)\end{array}$ & $\begin{array}{l}0.29 \pm 0.05 \\
(0.09-1.45)\end{array}$ & $\begin{array}{l}0.23 \pm 0.04 \\
(0.07-0.86)\end{array}$ \\
\hline $\mathrm{Cu}$ & $\begin{array}{l}0.55^{\mathrm{A}} \pm 0.03 \\
(0.34-0.80)\end{array}$ & $\begin{array}{l}0.71^{\mathrm{B}} \pm 0.03 \\
(0.56-0.93)\end{array}$ & $\begin{array}{l}0.55^{\mathrm{A}} \pm 0.02 \\
(0.46-0.70)\end{array}$ & $\begin{array}{l}0.52^{\mathrm{A}} \pm 0.03 \\
(0.30-0.70)\end{array}$ & $\begin{array}{l}0.59^{\mathrm{AB}} \pm 0.06 \\
(0.30-0.96)\end{array}$ & $\begin{array}{l}0.63^{\mathrm{Y}} \pm 0.02 \\
(0.41-0.96)\end{array}$ & $\begin{array}{l}0.54^{\mathrm{X}} \pm 0.02 \\
(0.30-0.78)\end{array}$ \\
\hline
\end{tabular}

Means for breeds denoted by different letters in rows differ statistically significantly: A, B, C $P<0.01$. Means for muscles denoted by different letters in rows differ statistically significantly: X, Y $P<0.01$; x, y $P<0.05$ 
$\mathrm{Fe}$, the differences were not confirmed statistically. Ramos et al. [5] analysed the content of microminerals ( $\mathrm{Se}, \mathrm{Cu}, \mathrm{Zn}$, $\mathrm{Fe}$ and $\mathrm{Mn}$ ) in the muscles of Hereford and Braford steers and found significantly higher content of $\mathrm{Cu}$ and lower content of $\mathrm{Fe}$ in the former. On the other hand, Cabrera et al. [1] noted significant differences in steers of these breeds only in the case of Mn.

Leheska et al. [12], in strip steaks from pasture-raised cattle, found similar content of $\mathrm{K}, \mathrm{Fe} \mathrm{Zn}$ and $\mathrm{Cu}$, higher $\mathrm{Na}$ and $\mathrm{Ca}$ and lower $\mathrm{Mg}$ and $\mathrm{Mn}$ than were found in the present study. Łozicki et al. [13] observed a higher level of $\mathrm{Na}, \mathrm{Zn}$ and $\mathrm{Fe}$ in the meat of young bulls raised on an organic farm (with a diet mainly based on pasture forage) than in animals fed on maize silage and concentrate feed. On the other hand, Holló et al. [11], in the LL muscle of young bulls fed extensively (green forage/haylage with concentrate feed and flax), demonstrated lower content of $\mathrm{Na}$ and $\mathrm{Cu}$ and a higher level of Fe than in intensively fed young bulls (maize silage and concentrate feed).

Pilarczyk [10] found that breed had a significant effect on the content of $\mathrm{K}, \mathrm{Mg}, \mathrm{Fe}, \mathrm{Zn}, \mathrm{Cu}$ and $\mathrm{Mn}$ in the meat of intensively fed young bulls of the breeds Charolais, Hereford and Simmental raised in northwestern Poland. According to the author, the differences observed between the breeds were determined by metabolism. These differences may have been determined not only genetically but also by excretion of endogenous $\mathrm{Cu}$ and by the amount of fodder consumed by the animals.

The present study showed that while the type of muscle did not affect the content of macrominerals, in the case of microminerals, the effect was significant. Significantly higher content of $\mathrm{Zn}, \mathrm{Fe}$ and $\mathrm{Cu}$ were noted in the LL muscle than in the ST (Table 3). Similarly, Florek et al. [14] demonstrated that the LL and ST muscles of two categories of PHF cattle differed significantly only for content of $\mathrm{Zn}, \mathrm{Mn}$ and $\mathrm{Cu}$. Ramos et al. [5] also found a significant influence of the muscle of steers on content of Se, Zn, Mn and Fe. The differences observed between muscles in the content of minerals may be linked to differences in their metabolic activity, fat content and blood circulation between organs $[15,16]$.

\section{Conclusions}

The breed of cattle was found to affect the content of $\mathrm{K}, \mathrm{Na}$, $\mathrm{Mg}, \mathrm{Ca}, \mathrm{Zn}, \mathrm{Mn}$ and $\mathrm{Cu}$ in the meat. The meat of the young PHF bulls contained smaller amounts of macrominerals (K, $\mathrm{Mg}$ and $\mathrm{Ca}$ ) and larger amounts of microminerals ( $\mathrm{Zn}, \mathrm{Fe}$ and $\mathrm{Mn})$ in comparison with the four other breeds.

Irrespective of the differences found, the meat of the cattle breeds evaluated is a valuable raw material containing nutritionally beneficial amounts of minerals, particularly $\mathrm{Zn}, \mathrm{Fe}$, $\mathrm{Mg}, \mathrm{Cu}$ and $\mathrm{K}$, as well as of $\mathrm{Na}$ (due to its low level).
However, further research should be conducted both to determine the content of nutrients in other muscles/meat cuts and to assess the effect of various culinary procedures on their preservation and bioavailability.

Acknowledgments Research was realised within the project "BIOFOOD - innovative, functional products of animal origin" no. POIG.01.01.02-014-090/09 co-financed by the European Union from the European Regional Development Fund within the Innovative Economy Operational Programme 2007-2013.

Open Access This article is distributed under the terms of the Creative Commons Attribution 4.0 International License (http:// creativecommons.org/licenses/by/4.0/), which permits unrestricted use, distribution, and reproduction in any medium, provided you give appropriate credit to the original author(s) and the source, provide a link to the Creative Commons license, and indicate if changes were made.

\section{References}

1. Cabrera MC, Ramos A, Saadoun A, Brito G (2010) Selenium, copper, zinc, iron and manganese content of seven meat cuts from Hereford and Braford steers fed pasture in Uruguay. Meat Sci 84(3): $518-528$

2. Schönfeldt HC, Naudé RT, Boshoff E (2010) Effect of age and cut on the nutritional content of South African beef. Meat Sci 86:674683

3. Williams P (2007) Nutritional composition of red meat. Nutr Diet 64(4):113-119

4. Williamson CS, Foster RK, Stanner SA, Buttriss JL (2005) Red meat in the diet. Nutr Bull 30(4):323-355

5. Ramos A, Cabrera MC, Saadoun A (2012) Bioaccessibility of Se, $\mathrm{Cu}, \mathrm{Zn}, \mathrm{Mn}$ and $\mathrm{Fe}$, and heme iron content in unaged and aged meat of Hereford and Braford steers fed pasture. Meat Sci 91(2):116-124

6. Mulvihill B, Morrissey PA (1998) An investigation of factors influencing the bioavailability of non-haem iron from meat systems. Irish J Agr Food Res 37(2):219-226

7. Litwińczuk Z, Żółkiewski P, Florek M, Chabuz W, Domaradzki P (2014) Semi-intensive fattening suitability and slaughter value of young bulls of 3 Polish native breeds in comparison with Polish Holstein-Friesian and Simmental. Ann Anim Sci 2:453-460

8. Cabrera MC, Saadoun A (2014) An overview of the nutritional value of beef and lamb meat from South America. Meat Sci 98(3):435-444

9. Florek M, Litwińczuk Z, Kędzierska-Matysek M, Grodzicki T, Skałecki P (2007) Nutritional value of meat from musculus longissimus lumborum and musculus semitendinosus of young slaughter cattle. Med Weter 63(2):242-246

10. Pilarczyk R (2014) Concentrations of toxic and nutritional essential elements in meat from different beef breeds reared under intensive production systems. Biol Trace Elem Res 158:36-44

11. Holló G, Nuernberg K, Holló I, Csapó J, Seregi J, Repa I, Ender K (2007) Effect of feeding on the composition of longissimus muscle of Hungarian Grey and Holstein Friesian bulls. III Amino acid composition and mineral content. Arch Tierz Dummerstorf 50(6): 575-586

12. Leheska JM, Thompson LD, Howe JC, Hentges E, Boyce J, Brooks JC, Shriver B, Hoover L, Miller MF (2008) Effects of conventional and grass-feeding systems on the nutrient composition of beef. $\mathrm{J}$ Anim Sci 86:3575-3585 
13. Łozicki A, Dymnicka M, Arkuszewska E, Pustkowiak H (2012) Effect of pasture or maize silage feeding on the nutritional value of beef. Ann Anim Sci 12(1):81-93

14. Florek M, Kędzierska-Matysek M, Litwińczuk A (2008) Macro and microelements content in meat of calves and young slaughter cattle. Pol J Environ Stud 17(1B):213-216

15. García-Vaquero M, Miranda M, Benedito JL, Blanco-Penedo I, López-Alonso M (2011) Effect of type of muscle and $\mathrm{Cu}$ supplementation on trace element concentrations in cattle meat. Food Chem Toxicol 49(6):1443-1449

16. López-Alonso M, Benedito JL, Miranda M, Castillo C, Hernández J, Shore RF (2000) Arsenic, cadmium, lead, copper and zinc in cattle from Galicia, NW Spain. Sci Total Environ 246(2-3):237248 